\title{
FAKTOR YANG BERHUBUNGAN TERHADAP TINGKAT KELULUSAN UKDI DOKTER BARU LULUSAN FAKULTAS KEDOKTERAN UNIVERSITAS AIRLANGGA
}

\author{
Budi Utomo, Roostantia, Indri Safitri \\ Fakultas Kedokteran, Universitas Airlangga Surabaya
}

\begin{abstract}
Background: The average passing rate of Airlangga University School of Medicine (accredited A) graduates on the Indonesian Doctor Competence Examinations (UKDI) from Batches 1 to 17 was in the range of 90-95\%, which was above the national average. The achievement, however, has declined to approximately 80-85\% in Batch 23 - the last UKDI. These school's new graduates are the product of a series of educational processes within the faculty of medicine: input in the form of student selection, educational process incorporating: educational programs, academic staff, educational resources, learning outcomes assessments, evaluation of educational programs and continuous updates, and the output which are medical doctors passing the UKDI. This study aims at exploring the factors that influence the success of newly graduated doctors to pass the UKDI. The results were expected to be used as considerations for the improvements of materials and teaching methods which referring to the National Competencies for Physician (SKDI). Method: The study was divided into two stages. Observational study design was implemented on the first stage. Second, the analytical observational cross-sectional study design was applied. The unit of analysis was derived from secondary data, a collection of documents of students studying in the School of Medicine Airlangga University and of the UKDI test scores.

Results: The analysis results showed that the variable most affecting the passing of UKDI in this study was the GPA at the bachelor stage $(O R=67.44 ; p=0.001)$. The mathematical model of the logistic regression is: $y=$ constant + a $1 x 1+$ $a 2 x 2+\ldots .+$ anxn, being $y=-8.83+67.44$ (GPA bachelor). The probability ( $p$ ) of passing a new doctor of the school on the UKDI examination can be predicted using the formula: $p=1 /(1+e-y)$, with $e=2.7$ (natural number).

Conclusion: The variable most affecting the passing of UKDI in this study was the GPA at the bachelor stage (OR = 67.44; $p=0.001$.
\end{abstract}

Keywords: influential factor, passing of UKDI

\section{ABSTRAK}

Latar Belakang: Rata-rata pencapaian tingkat kelulusan dari FKUA (terakreditasi A) pada UKDI mulai angkatan ke-1 hingga ke-17 adalah berkisar 90-95\%, diatas rata-rata nasional, tetapi pencapaian terakhir pada UKDI ke-23 menurun menjadi sekitar 80-85\%. Dokter baru sebagai suatu produk dari fakultas kedokteran merupakan hasil dari serangkaian proses. Input berupa seleksi mahasiswa. Proses pendidikan mencakup: program pendidikan, staf akademik, sumber daya pendidikan, penilaian hasil belajar, evaluasi program pendidikan dan update berkesinambungan. Output berupa dokter lulus UKDI. Penelitian ini bertujuan mempelajari faktor-faktor yang berpengaruh terhadap keberhasilan dokter baru lulus UKDI. Hasilnya dapat dipakai sebagai pertimbangan untuk bahan dan metode pengajaran KBK yang mengacu SKDI.

Metode: Jenis dan rancangan penelitian ini dibagi dalam dua tahap; pertama menggunakan disain penelitian observasional deskriptif, kedua observasional analisis dengan pendekatan disain cross sectional study. Unit analisis berasal dari data sekunder, berupa kumpulan dokumen mahasiswa selama menempuh pendidikan di FK Unair dan dokumen nilai hasil UKDI.

Korespondensi: budiutomo@gmail.com 
Hasil: Hasil analisis menunjukkan bahwa variabel yang paling berpengaruh terhadap kelulusan UKDI pada penelitian ini adalah nilai IPK pada waktu lulus menjadi sarjana kedokteran (S.Ked). Kekuatan hubungan ini dapat dilihat dari nilai OR (Exp (B)), sebesar 67,44. Persamaan yang didapatkan pada uji regresi logistik adalah: $\mathrm{y}=$ konstanta $+\mathrm{a} 1 \mathrm{x} 1+\mathrm{a} 2 \mathrm{x} 2+\ldots . .+$ anxn, menjadi $\mathrm{y}=-8,83+67,44$ (IPK S.Ked). Besarnya probabilitas (p) kelulusan dokter baru FKUA dari UKDI, dipakai rumus: $\mathrm{p}=1 /(1+\mathrm{e}-\mathrm{y})$, dengan $\mathrm{e}=2,7$ (bilangan natural)

Kesimpulan: Variabel yang paling berpengaruh terhadap kelulusan UKDI pada penelitian ini adalah nilai IPK pada waktu lulus menjadi sarjana kedokteran (S.Ked).

Kata kunci: faktor yang berpengaruh, kelulusan, UKDI

\section{PENDAHULUAN}

Uji kompetensi dokter Indonesia (UKDI) telah dilaksanakan sejak tahun 2007, dengan frekuensi pelaksanaan sebanyak empat kali dalam setahun. Pelaksanaan UKDI XVII ini sesuai dengan perkembangan metode ujian dan teknologi informasi, saat ini berbasis komputer (CBT= Computer-based test). ${ }^{1}$ Hal ini bertujuan untuk meningkatkan kualitas tampilan, mempercepat proses analisis soal dan pengumuman, sehingga mempersingkat waktu yang diperlukan untuk terjun ke masyarakat melalui program internship. ${ }^{2}$ Pelaksanaan ujian dengan komputer ini telah didahului dengan uji coba sebanyak empat kali selama tahun 2010-2011 di seluruh Indonesia. Standar prosedur operasional telah mengalami perbaikan terus-menerus mendorong pelaksanaan UKDI berdasar CBT ini bisa berjalan dengan lancar. Peserta baru mendapatkan Sertifikat Kompetensi setelah lulus UKDI, yang menjadi salah satu syarat dalam proses mendapatkan Surat Tanda Registrasi (STR). STR ini merupakan salah satu syarat untuk mendapat Surat Ijin Praktek (SIP). ${ }^{3}$

Pelaksanaan dan penyelenggaraan UKDI sejauh ini, menimbulkan beberapa permasalahan, antara lain dokter baru yang tidak lulus, sehingga jumlah retaker setiap tahun meningkat. Tingkat kelulusan UKDI bagi mahasiswa lulusan fakultas kedokteran tidak berbanding lurus dengan akreditasi dari fakultas kedokteran yang bersangkutan. Rata-rata pencapaian tingkat kelulusan dari FKUA (terakreditasi A) pada UKDI dari angkatan ke-1 sampai dengan ke-17 adalah berkisar 90-95\%, diatas rata-rata nasional, tetapi pencapaian terakhir pada UKDI ke-23 yang baru lalu menurun menjadi sekitar $80-85 \%$. Harapan ini jauh diluar prediksi yang diharapkan, yang minimal diharapkan bisa mencapai rentang $95 \%$ sampai dengan 98\% kelulusan, tapi pencapaian ini justru semakin turun.

Dokter baru sebagai suatu produk dari fakultas kedokteran yang merupakan serangkaian proses: inputproses-output, dengan output yang diharapkan tidak sekedar menjadi dokter baru saja, tetapi dokter yang lulus UKDI. Input berupa seleksi atau penerimaan mahasiswa. Proses pendidikan mencakup: program pendidikan, staf akademik, sumber daya pendidikan, penilaian hasil belajar, evaluasi program pendidikan dan update berkesinambungan, dengan output berupa dokter lulus UKDI. ${ }^{4}$ Tujuan umum penelitian ini adalah untuk menganalisis factor-faktor yang berhubungan terhadap tingkat kelulusan UKDI. Hal ini bertujuan untuk meningkatkan kapasitas staf dosen FKUA dalam sistem ujian berupa pengembangan soal dan pemahaman tentang sistem ujian. Praktik ini selanjutnya diharapkan bisa meningkatkan kualitas pelayanan kesehatan di Indonesia. Sehingga dihasilkan suatu standar penilaian (evaluasi) lulusan dokter baru FKUA, setelah menjalani masa studi keseluruhan di FKUA.

\section{METODE}

\section{Jenis dan Rancangan Penelitian}

Penelitian ini merupakan studi potong lintang yang dibagi dalam dua tahap. Tahap pertama, dengan menggunakan disain penelitian observasional deskriptif. Kedua, dengan menggunakan metode penelitian analisis observasional dengan pendekatan disain cross sectional study.

Desain penelitian ini, mempelajari variabel faktor risiko (nilai IPK, masa studi kelulusan, cara masuk FK) dan variabel akibat (kelulusan UKDI) pada waktu yang 
bersamaan. Data penelitian yang diperlukan diambil dari data sekunder, berupa kumpulan dokumen pendidikan mahasiswa selama menempuh pendidikan di FK dan dokumen nilai hasil UKDI.

\section{Tahapan Penelitian}

Tahap 1 deskriptif: Tahapan penelitian observasional deskriptif: 1) Pemilihan masalah yang akan diteliti (faktor risiko: cara seleksi/cara masuk mahasiswa, masa studi, nilai IPK, aktifitas mahasiswa selama masa studi), 2) Perumusan dan membatasi masalah penelitian, 3) merumuskan hipotesis (tidak harus/ perlu), 3) Pemilihan tehnik pengumpulan data, 4) Penentuan kriteria untuk klasifikasi data, 4) Penentuan alat pengumpul data, 5) pengolahan data dan terakhir 6) Penarikan kesimpulan.

Tahap 2 analitik: dengan analisis bivariat, kemudian dilanjutkan dengan analisis multivariat.

\section{Variabel Penelitian}

Tabel 1. Daftar rencana variabel penelitian

\begin{tabular}{llll} 
No & Variabel & $\begin{array}{l}\text { Kode/ } \\
\text { Sumber }\end{array}$ & Keterangan \\
\hline 1 & ID Mahasiswa & Dokumen & NIM \\
2 & Umur & Fendidikan & Dalam tahun \\
3 & Jenis kelamin & FKUA & Pria/ Wanita \\
4 & Cara masuk FK/ seleksi & & Dalam tahun \\
5 & Lama masa studi & & Angka \\
6 & IPK sarjana (dokter & & Angka \\
7 & muda) & & Angka \\
8 & IPK sarjana (dokter) & & Angka \\
9 & Nilai UKDI dalam tahun & & Angka \\
10 & Skor min dalam tahun & & Angka \\
11 & Skor maks dalam & & Angka \\
12 & Frekuensi ikut UKDI & & Ya/Tidak \\
13 & Ikut bimbingan & & Lulus/ Tidak lulus \\
& Kelulusan UKDI & & \\
\hline
\end{tabular}

\section{Manajemen dan Analisis Data}

Manajemen data: Tahapan manajemen atau penyuntingan data meliputi: menyunting data (data editing), mengkode data (data coding), membuat struktur data dan file data, memasukkan data (data entry) dan membersihkan data (data cleaning).
Analisis data: 1) Analisis deskriptif: data hasil penelitian ditampilkan dalam tabel distribusi frekuensi dan diagram. 2) Analisis analitik: analisis bivariat: dilakukan untuk mengetahui adanya perbedaan dan hubungan atau korelasi antara dua variabel yang diteliti. Analisis multivariat: untuk mengetahui adanya hubungan atau pengaruh beberapa variabel bebas dengan suatu variabel terikat secara simultan atau bersamaan. Analisis multivariat yang digunakan pada penelitian ini adalah dikerjakan dengan bantuan komputer memakai software SPSS, yaitu analisis regresi logistik.

\section{HASIL DAN PEMBAHASAN}

\section{Profil Fakultas Kedokteran Universitas Airlangga}

Fakultas Kedokteran Universitas Airlangga (FKUA) merupakan salah satu fakultas kedokteran tertua di Indonesia, dan telah mendapatkan akreditasi A dari Badan Akreditasi Nasional Perguruan Tinggi (BAN-PT). Kini FKUA mempunyai lebih kurang 29 departemen dengan 36 program studi (prodi), mulai dari jenjang D-3 sampai dengan S-3, serta program pendidikan dokter spesialis (PPDS). FKUA hingga kini telah meluluskan sekitar sembilan ribuan dokter, yang tersebar selain di seluruh Indonesia, juga di berbagai belahan dunia lainnya. Daya tampung pendidikan dokter sekitar 220 mahasiswa per tahun. Rata-rata setiap tahunnya FKUA berhasil meluluskan lebih kurang 220 dokter.

\section{Pelaksanaan UKDI di FKUA}

Pelaksanaan UKDI, dalam setahun dilaksanakan sebanyak empat kali, yaitu setiap bulan Februari, Mei, Agustus dan Nopember. UKDI di FKUA telah berlangsung sejak tahun 2007 dan dilandasi oleh UU No. 29 tahun 2004 tentang praktik kedokteran. Saat ini, ada dua jenis UKDI yaitu CBT (computer-based testing/ ujian tulis) dan OSCE (objective structued clinical examination/ujian praktek). Sampai dengan bulan September 2013, FKUA telah melaksanakan UKDI-CBT yang ke-25 (batch 3) dan OSCE ketiga. Rata-rata kelulusan dokter baru FKUA di UKDI adalah sekitar 90-95\% pertahunnya untuk first taker. 
Profil Lulusan Dokter FKUA yang Menjadi Subjek PenelitianUKDI 2013

Tabel 2. Distribusi umur, masa studi, pencapaian IPK dan nilai UKDI pada responden penelitian

\begin{tabular}{lccccc} 
& $\mathbf{n}$ & minimum & maximam & mean & std. deviation \\
Umur (tahun) & 315 & 23,00 & 36,00 & 25,8222 & 1,87851 \\
Lama studi S.Ked (tahun) & 315 & 4 & 7 & 4,10 & 0,428 \\
Lama studi dokter (tahun) & 315 & 5 & 14 & 5,63 & 1,253 \\
IPK sarjana kedokteran & 315 & 1,98 & 3,75 & 2,9453 & 0,37333 \\
IPK dokter & 315 & 2,20 & 3,78 & 3,2639 & 0,21819 \\
Nilai UKDI & 315 & 41,50 & 88,00 & 71,1841 & 7,72493 \\
\hline
\end{tabular}

Tabel 2 ini menunjukkan distribusi umur, masa studi, pencapaian IPK dan nilai dan memberikan gambaran nilai minimum, maksimum, rata-rata (mean) dan standar deviasi dari variabel umur, lama studi untuk

\section{Hasil UKDI FKUA}

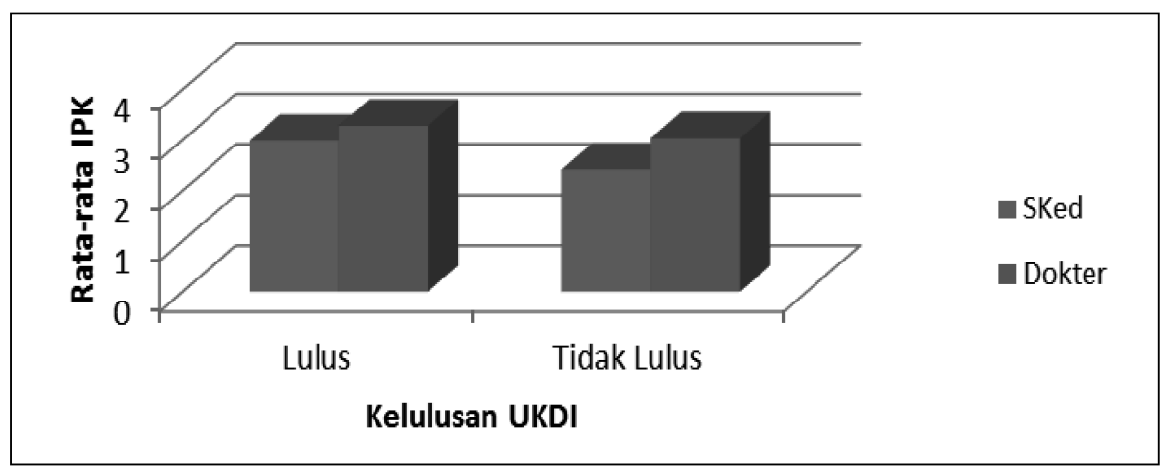

Gambar 1. Distribusi kelulusan UKDI berdasarkan pencapaian IPK

Gambar 1 menggambarkan proporsi IPK peserta UKDI, baik ditingkat sarjana kedokteran (S.Ked) maupun tingkat profesi (dokter), lebih besar nilai IPK yang lulus UKDI, daripada yang tidak lulus.

mencapai sarjana. kedokteran dan lulus dokter, IPK serta nilai UKDI dari responden penelitian yang seluruhnya mencapai 315 responden.

baik ditingkat sarjana kedokteran (S.Ked) maupun UKDI, daripada yang tidak lulus.

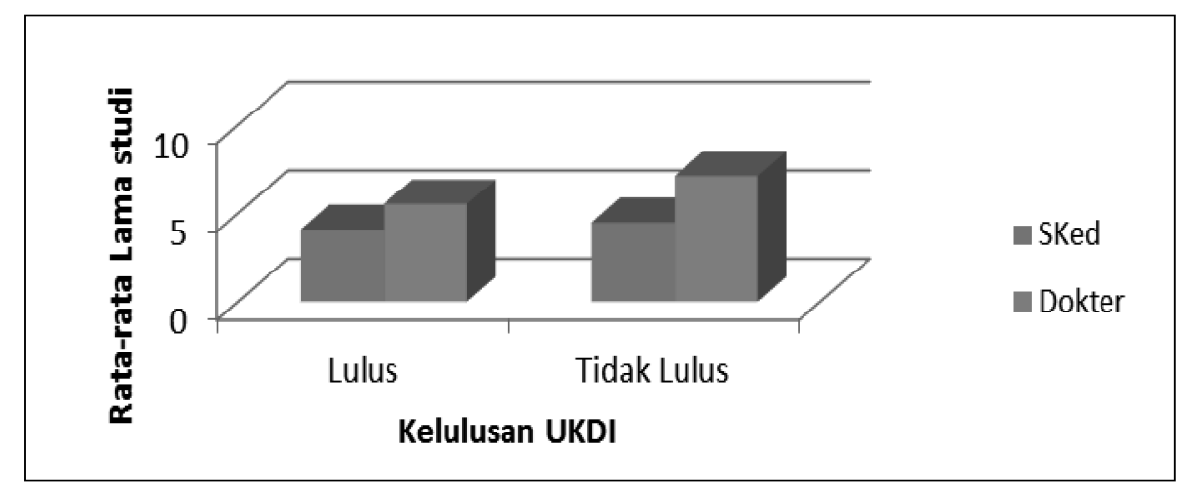

Gambar 2. Distribusi kelulusan UKDI berdasarkan lama masa studi di FKUA 
Gambar 2 menunjukkan mereka yang tidak lulus UKDI mempunyai masa studi yang lebih panjang bila dibandingkan yang lulus.

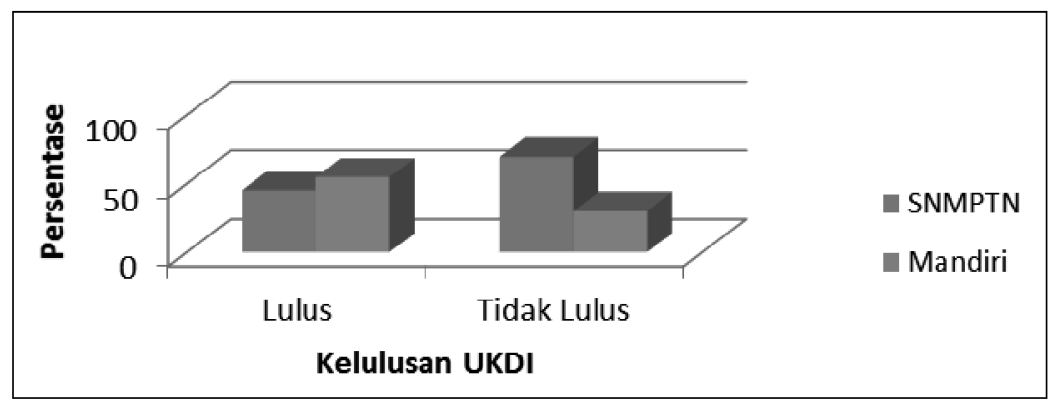

Gambar 3. Distribusi kelulusan UKDI berdasarkan proporsi cara masuk FKUA

Gambar 3 tersebut di atas sepertinya memberikan hasil yang bertolak belakang antara mereka peserta UKDI yang lulus dengan yang tidak lulus. Kelompok yang lulus UKDI lebih besar dari mereka yang memasuki FKUA yang berasal dari jalur mandiri.

\section{Hasil Analisis Bivariat}

Hubungan antara kelulusan UKDI dengan IPK, Lama Studi dan Jalur Penerimaan dianalisis dengan uji MannWhitney. Hasil Uji Mann-Whitney antara kelulusan UKDI dengan IPK Sarjana Kedokteran memberikan kesimpulan bahwa, ada perbedaan yang signifikan antara tingkat kelulusan UKDI dengan rata-rata IPK Sarjana Kedokteran $(p<0,05)$.

\section{Hasil Analisis Multivariat}

Hasil analisis uji Mann-Whitney antara tingkat kelulusan UKDI terhadap lama masa studi untuk menempuh gelar sarjana kedokteran, maupun masa studi untuk mendapatkan gelar dokter, keduanya menunjukkan adanya perbedaan yang signifikan, antara kelompok yang lulus dan yang tidak lulus UKDI. $(p<0,05)$.

Hasil uji hubungan dengan chi-square test antara kelulusan UKDI dengan jalur penerimaan mahasiswa baru di FKUA, menunjukan adanya korelasi atau

hubungan antara kelulusan UKDI dengan dengan jalur penerimaan mahasiswa baru di FKUA. $(p<0,05)$ dibandingkan yang lulus.

Tabel 3. Hasil analisis multivariat

\begin{tabular}{lllllll} 
& & & & \multicolumn{3}{c}{$95 \%$ C,I } \\
& & B & Sig, & Exp(B) & Lower & Upper \\
\hline Step $1^{a}$ & IPK S.Kcd & 3,936 & 0,001 & 51,229 & 7,139 & 367,639 \\
& IPK dr & 1,800 &, 226 & 6,051 &, 329 & 111,476 \\
& Lama lulus sked &, 505 &, 291 & 1,657 &, 649 & 4,231 \\
& Lanld lulus dokler &,- 087 &, 686 &, 916 &, 600 & 1,400 \\
& JALUR(1) &,- 769 &, 160 &, 464 &, 159 & 1,355 \\
& Konstanta & $-14,862$ &, 004 & 0,001 & & \\
\hline Step 2 ${ }^{a}$ & IPK S.Ked & 4,051 & 0,001 & 57,430 & 8,675 & 380,214 \\
& IPK dr & 1,883 &, 192 & 6,570 &, 389 & 110,835 \\
& Lama lulus S.Ked &, 384 &, 301 & 1,468 &, 710 & 3,036 \\
& jalur(1) &,- 824 &, 119 &, 438 &, 156 & 1,235 \\
& Konstanta & $-15,424$ &, 002 & 0,001 & & \\
\hline
\end{tabular}


Tabel 3. Hasil analisis multivariat (lanjutan)

\begin{tabular}{lllllll} 
& & & & \multicolumn{3}{c}{$95 \%$ C,I } \\
& & B & Sig, & Exp(B) & Lower & Upper \\
Step $3^{a}$ & IPK S.Ked & 3,600 & 0,001 & 36,600 & 7,025 & 190,685 \\
& IPK dr & 1,740 &, 225 & 5,698 &, 342 & 94,866 \\
& jalur(1) &,- 785 &, 136 &, 456 &, 163 & 1,279 \\
& Konstanta & $-12,191$ &, 002 & 0,001 & & \\
\hline Step 4 & IPK S.Ked & 4,177 & 0,001 & 65,165 & 15,393 & 275,867 \\
& jalur(1) &,- 810 &, 122 &, 445 &, 159 & 1,243 \\
& Konstanta & $-8,254$ & 0,001 & 0,001 & & \\
\hline Step 5 $5^{a}$ & IPK S.Ked & 4,211 & 0,001 & 67,442 & 16,374 & 277,784 \\
& Konstanta & $-8,830$ & 0,001 & 0,001 & & \\
\hline
\end{tabular}

Lima variabel yang dimasukkan secara simultan pada analisis multivariat ini adalah: IPK sarjana kedokteran dan dokter, lama lulus sarjana kedokteran dan dokter, serta variabel jalur penerimaan mahasiswa baru dalam pengaruhnya terhadap kelulusan dokter baru tersebut dalam mengikuti UKDI. Pengerjaan dengan metode backward stepwise, terdapat lima langkah untuk sampai pada hasil akhir. Variabel yang secara signifikan dan konsisten dalam mempengaruhi kelulusan UKDI tersebut adalah hanya variabel IPK sarjana kedokteran. Kekuatan hubungan ini dapat dilihat dari nilai OR (Exp (B)), yaitu sebesar $\mathrm{OR}=67,44$.

Persamaan yang didapatkan pada uji regresi logistik adalah :

$\mathrm{y}=$ konstanta $+\mathrm{a} 1 \mathrm{x} 1+\mathrm{a} 2 \mathrm{x} 2+\ldots . .+$ anxn

$y=-8,83+67,44($ IPK S.Ked)

Aplikasi dari persamaan yang didapat adalah untuk memprediksi probabilitas untuk lulus UKDI, dipakai rumus: $\mathrm{p}=1 /(1+\mathrm{e}-\mathrm{y})$, dengan ketentuan:

$\mathrm{p}=$ probabilitas untuk lulus UKDI

$\mathrm{e}=2,7$ (bilangan natural)

\section{Pelaksanaan UKDI di FKUA}

Hasil UKDI tidak selalu sesuai dengan yang diperkirakan diatas kertas. Universitas dengan akreditasi A ternyata rata-rata nilai UKDI mahasiswanya tidak memenuhi harapan sedangkan yang berakreditasi rendah dapat membuktikan dirinya sendiri melalui UKDI. UKDI juga dapat menjadi bahan evaluasi bagi institusi pendidikan untuk meningkatkan kualitas lulusannya. ${ }^{5}$ Hasil evaluasi UKDI ini sendiri tidak bisa dilepaskan dari peran sistem pendidikan dan pengajaran di fakultas kedokteran yang sekarang sudah mengacu pada kurikulm berbasis kompetensi. ${ }^{6}$

Pada kurikulum inti dan institusional di tahun 2000, terjadi perubahan konsep; kurikulum didorong oleh beberapa masalah global atau eksternal terutama yang diuraikan dalam laporan UNESCO. Kurikulum lebih didasarkan pada rumusan kompetensi yang harus dicapai oleh lulusan perguruan tinggi yang mendekati kompetensi yang dibutuhkan olehmasyarakat pemangku kepentingan. Kurikulum ini, oleh karenanya disebut dengan competence-based curriculum. ${ }^{2,7}$

\section{Profil Lulusan Dokter FKUA yang Menjadi Subjek Penelitian UKDI 2013}

Undang-undang Pendidikan Kedokteran yang baru saja disahkan oleh DPR membawa era baru pada pendidikan kedokteran, yang lebih memperhatikan keadilan bagi seluruh mahasiswa kedokteran, pemerataan pendidikan, dan peningkatan mutu pendidikan. Asumsi bahwa pada jenjang pendidikan tinggi lebih banyak didominasi oleh mahasiswa laki-laki daripada perempuan, di era sekarang sudah tidak ada lagi. Responden penelitian ini kebetulan lebih banyak mahasiswinya daripada mahasiswa, mungkin mahasiswi lebih telaten dan sabar daripada mahasiswa yang memang sangat diperlukan pada pendidikan kedokteran, yang mewajibkan mahasiswa harus banyak membaca dan melakukan banyak latihan kajian analisis masalah. Undang-undang ini membuka 
kesempatan lebih lebar bagi masyarakat menengah kebawah untuk menempuh dunia kedokteran. Hasil penelitian yang sama ditunjukan oleh Reimer dan Steinmetz ${ }^{8}$ di Jerman untuk tingkat pendidikan sarjana, bahkan sampai di tingkat lapangan kerja tidak, ada perbedaan dalam hal jumlah atau proporsi antara jenis kelamin perempuan dan laki-laki.

\section{Tahun Pertama Sebagai Mahasiswa dan Kelulusan Dokter Baru FKUA}

Rentang tahun angkatan responden pada penelitian UKDI ini adalah dari tahun 1995 sampai dengan tahun 2007. Rentang ini cukup lebar (lebih dari sepuluh tahun), namun demikian dominasi terbanyak didapat dari mahasiwa angkatan tahun 2004 sampai dengan 2006. Hal ini bisa dimaklumi oleh karena tahun pelaksanaan UKDI pada waktu data ini dianalisis adalah tahun 2011-2012. Tahun yang merupakan lanjutan yang memang harus mereka jalani untuk ikut UKDI, setelah lulus sebagai seorang dokter baru. Para dokter dari angkatan lainnya, yang lulus sebelum tahun tersebut, bisa ikut UKDI di tahun 2011-2012. Kemungkinan mereka sudah pernah ikut UKDI di tahun sebelumnya, tapi belum lulus, sehingga responden terbanyak adalah jelas dari angkatan tahun pada waktu penelitian ini dilaksanakan.

Situasi dan kondisi yang sama dapat diamati pada tahun kelulusan responden penelitian ini. Mereka yang lulus tepat waktu akan membutuhkan sekitar lima sampai enam tahun, sehingga dominasi terbanyak adalah mereka yang lulus pada tahun 2010/2011 sampai dengan 2011/2012. Sebagian kecil dari para dokter yang ikut UKDI sebagai respoden penelitian ini, lulus pada tahun sebelum 2010/2011.

\section{Jalur Mahasiswa Baru dan Lama Masa Studi di FKUA}

Responden peserta UKDI tahun 2012, yang berarti mereka lulus sebagai dokter baru di tahun 2012 itu juga, terdapat tiga jalur untuk bisa diterima sebagai mahasiswa baru FKUA. Jalur pertama melalui SNMPTN, kedua melalui jalur mandiri, dan ketiga dari jalur prestasi. Responden dengan proporsi terbanyak pada penelitian ini berasal dari jalur mandiri, namun selisihnya tidak besar, sekitar tujuh persen, sehingga komposisi peserta antara jalur SNMPTN dengan mandiri hampir sama besar, yaitu 47 dan 53\%.

Lama masa studi pada responden penelitian UKDI ini bervariasi dalam rentang paling singkat 5 tahun dan terpanjang sampai dengan 14 tahun. Salah satu indikator keberhasilan mahasiswa dalam menempuh pendidikan dokter yang memang sudah terkenal membutuhkan waktu lebih lama untuk lulus dari pada jenjang kesarjanaan lainnya adalah lulus tepat waktu. Rentang yang panjang dari responden penelitian ini menunjukkan bahwa ada banyak faktor yang terlibat yang mempengaruhi kelulusan mahasiswa dalam mendapatkan gelar dokter.

Pada dasarnya setiap satuan pendidikan memiliki sistem untuk menghasilkan lulusan yang berkualitas. Sistem pendidikan tinggi dilihat sebagai sebuah proses akan memiliki empat tahapan pokok yaitu (1) Masukan; (2) Proses; (3) Luaran; dan (4) Hasil ikutan (outcome). ${ }^{4}$ Faktor yang termasuk dalam kategori masukan antara lain adalah dosen, mahasiswa, buku, staf administrasi pendidikan dan teknisi, sarana dan prasarana, dana, dokumen kurikulum, dan lingkungan.

Mahasiswa yang merpakan salah satu katagori 'masukan' dalam sistem Perguruan Tinggi (PT), adalah lulusan SMU dan sederajat yang mendaftarkan diri untuk berpartisipasi dalam proses pembelajaran yang telah ditawarkan. Calon mahasiswa yang baik memiliki beberapa indikator, tidak hanya nilai kelulusan yang baik, namun terlebih penting adalah adanya sikap dan motivasi belajar yang memadai. PT yang ada semakin dikenal oleh masyarakat, maka semakin baik kualitas calon mahasiswanya. Hal ini disebabkan, PT tersebut menjadi sasaran favorit bagi lulusan SMU/SMK sederajat yang ingin meneruskan pendidikannya. ${ }^{2}$ Faktor lain yang mempengaruhi keberhasilan seorang mahasiswa untuk menempuh pendidikan tinggi, khususnya di fakultas kedokteran adalah dituntut mempunyai sikap kemandirian yang tinggi. Butler ${ }^{9}$ mengemukakan bahwa, self regulated learning merupakan siklus kegiatan kognitif yang berulang-ulang, yang memuat kegiatan seperti menganalisis tugas, memilih, mengadopsi, dan/atau menemukan pendekatan strategi untuk menyelesaikan tujuan, tugas, dan memantau hasil dari strategi yang telah dikerjakan. 
Distribusi Responden Peserta UKDI Berdasarkan Indeks Prestasi Kumulatif (IPK) di FKUA

Dalam pendidikan profesi dokter,nilai standar kelulusan profesi minimal adalah 65 atau kalau dikonversikan dalam skala nilai adalah B (dengan faktor pengali sebesar tiga poin), sehingga bila mendapatkan nilai dibawah 65 dapat dipastikan mahasiswa tersebut harus mengulang. Seorang mahasiswa yang lulus dari ujian tahap profesi (dokter), dapat dipastikan minimal akan mendapatkan nilai $\mathrm{B}$, tidak mungkin mendapatkan nilai $\mathrm{C}$, karena nilai $\mathrm{C}$ berarti sama dengan tidak lulus. Hal ini berbeda dengan nilai kelulusan pendidikan pada tahap akademik (sarjana kedokteran), nilai kelulusan minimal adalah $\mathrm{C}$, meskipun nilai $\mathrm{C}$ masih mendapatkan kesempatan untuk memperbaiki atau meningkatkan nilainya ke tingkat lebih tinggi (B). Hal ini menyebabkan distribusi nilai pada tahap pendidikan profesi rata-rata nilai IPKnya dapat dipastikan lebih tinggi daripada rata-rata nilai IPK yang dicapai pada tahap sarjana kedokteran. Dominasi distribusi nilai pada penelitian ini adalah berada pada kisaran tiga sampai dengan tiga setengah dan diatas tiga setengah poin. ${ }^{10}$

\section{Faktor yang Mempengaruhi Kelulusan UKDI}

Komparasi kelulusan UKDI dengan IPK sarjana kedokteran: perbedaan yang signifikan antara tingkat kelulusan UKDI dengan nilai rata-rata IPK sarjana kedokteran, hal ini menunjukkan bahwa, pengetahuan dasar kedokteran dan pengetahuan klinis dasar sebagian besar memang sudah diberikan pada empat tahun pertama dalam pendidikan mereka sebagai dokter. Sementara itu dalam satu setengah sampai dua tahun berikutnya pada tahap pendidikan profesi, mereka mendapatkan sebagian besar muatan profesi sebagai dokter. Nilai batas lulus (NBL) diantara kedua tahap atau jenjang pendidikan akademis dan profesi tersebut memang sudah berbeda, dengan tahapan pendidikan profesi NBL-nya lebih tinggi, dari pada jenjang akademis. Hal ini telah menjelaskan kenapa hasil uji MannWhitney menyatakan ada perbedaan yang signifikan antara tingkat kelulusan UKDI dengan rata-rata IPK Sarjana Kedokteran.

\section{Komparasi kelulusan UKDI dengan IPK dokter}

Peningkatan NBL pada tahap pendidikan profesi dokter dengan nilai minimal kelulusan adalah 65 (B), hal ini menyebabkan adanya persaingan yang ketat dalam belajar untuk memperjuangkan kelulusannya. Nilai IPK yang yang hanya sekedar lebih tinggi dari 3 tidak menjamin mereka bisa lulus UKDI, apalagi kalau lebih tingginya hanya sekedarnya saja. Perlu IPK yang jauh melampaui angka tiga untuk mendapatkan posisi yang aman dalam kelulusan UKDInya, karena sudah pasti semua IPK dokter baru tersebut minimal sudah mencapai IPK tiga atau lebih. Mahasiswa yang sudah dalam tahap pendidikan profesi dokter, bila dalam ujian mendapatkan nilai kumulatif dibawah 65 , masih dinyatakan belum lulus. ${ }^{10,11}$

\section{Komparasi kelulusan UKDI dengan lama kelulusan studi}

Kelompok yang lulus UKDI mempunyai rata-rata lama kelulusan baik ditingkat sarjana kedokteran maupun dokter, dengan lama waktu yang lebih singkat daripada mereka dengan kelompok yang tidak lulus UKDI. Hal ini bisa dipahami bahwa mereka yang lulus tepat waktu, baik ditingkat sarjana kedokteran ataupun dokter berarti merupakan produk lulusan yang lebih teruji, dibuktikan mereka termasuk kelompok yang lolos UKDI. Mereka yang semakin lama lulus, semakin sulit untuk sekali mengikuti UKDI, langsung lolos. Mahasiswa yang menempuh masa studi lebih lama berarti mereka mempunyai banyak masalah yang mengikutinya. Beberapa masalah itu antara lain adalah: sudah bekerja semenjak mahasiswa, telah berkeluarga, rasa kejenuhan itu sendiri karena lama tidak lulus dan sebagainya.

\section{Hubungan kelulusan UKDI dengan jalur penerimaan mahasiswa baru}

Korelasi yang terdapat antara tingkat kelulusan mahasiswa yang mengikuti UKDI dengan jalur penerimaan saat mereka menjadi mahasiswa baru adalah lemah dan mempunyai arah yang negatif, meskipun cukup signifikan. Hal ini berarti mereka yang diterima melalui jalur SNMPTN mempunyai kesempatan yang lebih kecil untuk lulus UKDI, bila dibandingkan dengan jalur mandiri. Korelasi ini mempunyai kekuatan yang lemah (13\%), banyak faktor yang ikut berperan dalam kelulusan UKDI. Salah satu faktor tersebut antara lain adalah proporsi jumlah responden yang berasal dari jalur mandiri lebih besar daripada SNMPTN. Kemungkinan lain adalah mahasiswa yang diterima melalui jalur 
mandiri mempunyai dorongan dan semangat belajar yang lebih kuat dan memang sudah seharusnya, karena disadari bahwa, mereka membayar lebih mahal dan perlu perjuangan ekstra saat masuk kuliah sebagai mahasiswa baru di FKUA. Mereka akan banyak merasa rugi kalau tidak serius menjalani kuliah, termasuk dalam menghadapi persiapan UKDI.

\section{Korelasi Nilai UKDI dengan IPK Sarjana Kedokteran, Lama Lulus Sarjana Kedokteran dan Lulus Dokter}

Nilai UKDI para responden pada penelitian ini masingmasing mempunyai korelasi Spearman yang signifikan dengan pencapaian IPK sarjana kedokteran, dengan arah korelasi yang positif dan kekuatan sedang. Lama masa studi menjadi dokter dan sarjana kedokteran, dengan kekuatan sedang dan mempunyai arah yang negatif. Hal ini berarti semakin lama masa studi untuk menjadi dokter ataupun sarjana kedokteran, maka semakin kecil nilai UKDI yang mereka dapatkan. Banyak masalah yang akan mereka hadapi, bila semakin lama mereka lulus. Hal ini bisa mengganggu kesiapan dalam menghadapi UKDI, yang akhirnya bisa mempengaruhi pencapaian nilai UKDInya.

Nilai IPK saat mereka lulus menjadi dokter, mempunyai korelasi Pearson yang signifikan terhadap pencapaian nilai UKDI, dengan kekuatan yang cukup kuat atau sedang, dan mempunyai arah postif. Nilai UKDI yang didapat akan semakin tinggi, bila pencapaian IPKnya juga semakin tinggi.

\section{Hasil Analisis Multivariat}

Lima variabel dianalisis secara simultan, yaitu IPK sarjana kedokteran dan IPK dokter, lama masa studi serta variabel jalur penerimaan sebagai mahasiswa baru FKUA dalam pengaruhnya terhadap kelulusan dokter baru tersebut saat mengikuti UKDI. Hasil analisis regresi logistik menghasilkan satu variabel saja yang signifikan, variabel tersebut adalah IPK sarjana kedokteran.

Rumus persamaan regresi logistiknya didapat sebagai berikut: $y=-8,83+67,44$ (IPK S.Ked), sedangkan untuk menghitung prediksi nilai probabilitas kelulusan UKDI digunakan rumus : $p=1 /(1+e-y)$. Analisis ini memungkinkan terjadinya eliminasi empat variabel, yang dalam analisis bivariat mempunyai korelasi yang signifikan. Hasil analisis multivariat ini ternyata menghasilkan hanya tinggal satu variabel saja yang mempunyai pengaruh, yaitu variabel IPK S.Ked. Proses ini terjadi karena adanya interaksi dari semua variabel tersebut yang saling berinteraksi. Interaksi yang terjadi adalah saling menghilangkan pengaruh, sampai tidak ada lagi variabel yang bisa dieliminasi dalam proses penghitungan regresi logistik. Proses analisis ini dikerjakan secara otomatis oleh software analisis statistik, dengan bantuan komputer.

Interpretasi lain yang bisa diberikan makna pada hasil analisis yang seperti demikian adalah bahwa, peran pendidikan profesi pada departemen klinik di rumah sakit kurang berperan dalam mempengaruhi tingkat kelulusan dokter baru FKUA dalam menghadapi UKDI. Konfirmasi mengenai hal tersebut bisa dilakukan dengan mengukur tingkat kelulusan OSCE bagi dokter baru lulusan FKUA.

\section{KESIMPULAN}

Faktor indeks prestasi kumulatif mahasiswa saat lulus sebagai sarjana kedokteran mempunyai pengaruh yang signifikan terhadap tingkat kelulusan pada uji kompetensi dokter Indonesia (UKDI), yang memenuhi persamaan regresi logistik y $=-8,83+67,44$ (IPK S.Ked), dengan probabilitas sebesar: $p=1 /(1+e-y)$.

\section{SARAN}

Indeks peramalan kelulusan UKDI bisa dibuat dengan lebih akurat bila data yang didapatkan tersedia lengkap seluruhnya dari UKDI angkatan pertama sampai terakhir. Kelengkapan data UKDI ini tidak tersedia di FKUA secara lengkap dan runtut, hanya sebagian kecil saja data yang bisa dianalisis. Diperlukan tenaga administrasi atau pendidikan yang khusus hanya menangani UKDI, mulai dari persyaratan pendaftaran hingga nilai itu bisa sampai ke tangan mahasiswa.

Perlu dilakukan penelitian lanjutan mengenai analisis faktor keberhasilan OSCE pada dokter baru lulusan FKUA, untuk mendapatkan gambaran menyeluruh tentang semua faktor yang mempengaruhi tingkat kelulusan UKDI, yang meliputi CBT dan OSCE. Diharapkan dengan penelitian lanjutan mengenai keberhasilan dalam melewati ujian OSCE nasional, akan 
dapat diketahui stase dan departemen mana yang mempunyai kontribusi rendah dalam kelulusan OSCE tersebut.

\section{DAFTAR PUSTAKA}

1. Thurlow, M., Lazarus, S. S., Albus, D., \& Hodgson, J. Computer-based testing: Practices and considerations, (Synthesis report 78). Minneapolis, MN:University of Minnesota, National Center on Educational Outcomes; 2010.

2. Direktorat Jenderal Pendidikan Tinggi, Direktorat Akademik. Buku panduan pengembangan KBK pendidikan tinggi, Jakarta: Kementerian Pendidikan Nasional; 2008.

3. Konsil Kedokteran Indonesia. Standar pendidikan profesi dokter Indonesia; 2012

4. Keputusan Rektor Unair No, 2994/JO3/PP/2003 tentang tata cara penilaian hasil belajar mahasiswa Unair; 2003.
5. Blerkom MV. Measurement and statistics for teachers. New York: Rotledge, Taylor \& Francis; 2009.

6. Harden RM, Shumway JM, 'The assessment of learning outcomes for the competent and reflective physician', Medical Teacher, 2003; 25(6): 569-84.

7. Harden, RM. AMEE Guide no, 21: Curriculum mapping: a tool for transparent and authentic teaching and learning, Medical Teacher, 2001; 23(2):123-37.

8. Steinmetz S, Reimer D. Gender differentiation in higher education: Educational specialization and labour market risks in Spain and Germany, Working paper, Arbeitspapiere - Mannheimer Zentrum fur Europäische Sozialforschung; 2007.

9. Butler, D.L, Individualizing instruction in Self-Regulated Learning. http//articles.findarticles.com/p/articles/ mi_mOQM/is_2_41/ni_90190495 ; 2002.

10. Kebijakan akademik fakultas kedokteran Universitas Airlangga; 2005.

11. Rencana strategis fakultas kedokteran Universitas Airlangga; 2012. 